\title{
Application of Peleg's equation to model the water absorption behaviour of green gram during soaking
}

\author{
Virendra Foke and Dhananjay Kulkarni
}

Author for Correspondence :

Virendra Foke Department of Agricultural Processing and Food Engineering, Shriram College of Agricultural Engineering, Paniv, Solapur (M.S.) India Email : virendrafoke@ gmail.com
ABSTRACT : The water absorption of green gram was studied by soaking in water at room temperature $\left(29^{\circ} \mathrm{C}\right), 40$ and $50^{\circ} \mathrm{C}$ in water bath upto $60 \mathrm{~min}$. Moisture content of green gram was increased from $11.01 \%$ d.b to $19.43,23.7$ and $30.27 \%$ d.b. as soaking temperature and time increased. The linear increase in moisture content was observed for each soaking temperature upto $60 \mathrm{~min}$. The water absorption data was modeled by using Peleg's model. Peleg's equation adequately described the soaking behaviour of sample using short time data under the experimental condition $\left(\mathrm{R}^{2} \geq 0.82\right)$. The Peleg's rate constant, $\mathrm{k}_{1}$ decreased from 6.658 to $2.034 \mathrm{~min} \% \mathrm{~d} . \mathrm{b}^{-1}$ while Peleg's capacity constant, $\mathrm{k}_{2}$ increased from $8 \times 10^{-3}$ to $2.08 \times 10^{-2}$ as temperature increased from 29 to $50^{\circ} \mathrm{C}$ for green gram demonstrating hydration rate decreased and absorption capacity increased with temperature. Both the Peleg's constants were expressed by a linear function $\left(\mathrm{R}^{2} \geq 0.86\right)$ for relating to with temperature. The modified Peleg's equation could be used for prediction of moisture content within experimental condition.

- KEY WORDS : Green gram, Water absorption, Peleg's model

- HOW TO CITE THIS PAPER : Foke, Virendra and Kulkarni, Dhananjay (2018). Application of Peleg's equation to model the water absorption behaviour of green gram during soaking. Internat. J. Agric. Engg., 11(2) : 369-372, DOI: 10.15740/HAS/IJAE/11.2/369-372. Copyright@ 2018: Hind AgriHorticultural Society. 